\title{
USP17L2 wt Allele
}

National Cancer Institute

\section{Source}

National Cancer Institute. USP17L2 wt Allele. NCI Thesaurus. Code C120055.

Human USP17L2 wild-type allele is located in the vicinity of 8p23.1 and is approximately 2 $\mathrm{kb}$ in length. This allele, which encodes ubiquitin carboxyl-terminal hydrolase 17 protein, is involved in the modulation of protein ubiquitination. 